\title{
Students' Perceptions of Autonomous Out-of-Class Learning through the Use of Computers
}

\author{
Xianghu Liu ${ }^{1}$ \\ ${ }^{1}$ College of Foreign Languages, Bohai University, China \\ Correspondence: Xianghu Liu, College of Foreign Languages, Bohai University, Jinzhou City 121013, Liaoning \\ Province, China. E-mail: liuxh863@gmail.com
}

Received: January 28, 2014 Accepted: February 22, 2014 Online Published: March 6, 2014

doi:10.5539/elt.v7n4p74 URL: http://dx.doi.org/10.5539/elt.v7n4p74

\begin{abstract}
This study investigates the attitudes towards, and practices of, computer-assisted autonomous learning in learning English of 160 students from three different higher education institutions in China. To do this, a questionnaire was completed by 160 participants, and follow-up in-depth interviews were undertaken with six participants and six of their teachers. The results from the findings and data analysis demonstrate students' attitudes towards computer-assisted autonomous English learning. Furthermore, the students have a positive view of computer-assisted autonomous learning. Also, it is believed that, with the development of Information Technology (IT), some English language learning problems, such as inefficient learning strategies and limited oral and listening ability that English teaching in China has faced for many years, may be solved. Finally, both the students and the teachers have made favourable comments on the effectiveness of computer assisted language learning, which is more effective than other ways to learn English. Based on the findings of this study, some main implications are presented. Recommendations are also made for enhancing teacher training, updating English coursebooks with relevant websites and investing more funds in learning facilities for higher education students.
\end{abstract}

Keywords: computer assisted language learning (CALL), learner autonomy, information technology (IT)

\section{Introduction}

Learner autonomy has come to be seen as increasingly important because it is linked to the successful development of learners' communication skills in foreign languages curricula. In addition, learner autonomy has been closely associated with new technologies since its emergence (Benson, 2011; Crabbe, 1993). As Schwienhorst (2007) points out, since the very beginning Computer Assisted Language Learning (CALL) has been associated with independent work, which is an important component of learner autonomy. Meanwhile, Pachler and Field (2001) argue that technological aids, which play a key role in the development of the four basic language skills, can be used effectively for independent work. Therefore, the aims of this study are to investigate student attitudes towards computer-assisted autonomous learning and provide some initial insights for teachers to consider how to enhance students' English language learning efficiency with the use of the computer.

\section{Literature Review}

The importance of learner autonomy is to enhance effective learning. Schwienhorst (2007) holds the view that learning is more effective if the learner integrates knowledge within a personal framework. Furthermore, autonomous learners become more highly motivated and autonomy leads to better, more effective work (Dickinson, 1995). Also, the relationship between motivation and autonomy is investigated and the research findings show that motivation is an important issue that influences the extent to which learners are ready to learn autonomously, and that teachers might therefore endeavour to develop student motivation before they are trained to become autonomous (Hafner \& Miller, 2011).

Moreover, the popularity of learner autonomy may be linked, at least partially, with the growth of computer technology and the increasing importance of computers in language learning environments worldwide (Schmenk, 2005). Schwienhorst (2007) argues that information technology has much to offer the fostering of autonomy due to its capacity to provide plentiful and varied opportunities for self-directed learning and to the possibility of 
using computers to deliver strategy training. Jones (2001) explores the relationship between computer-assisted language learning and autonomy, emphasizing the role of the teacher in employing technology, notably in the form of computers, as an effective learning opportunity. These findings indicate that the promotion of learner autonomy in the language learning context is a key factor in the successful exploitation of digital technologies for progress in second language learning.

Reinders (2007) suggests that technology can be a valuable tool for autonomous learning, providing help in setting goals, making progress towards achieving them, and gathering information for self-assessment. In summary, from the previous research, the combination of learner autonomy and the use of modern technology is one of the most important factors supporting language learning and enhancing learning efficiency.

\section{Research Design}

The main aim of this study was to investigate Chinese college students' attitudes towards, and experience of, computer-assisted autonomous learning. In order to do this, learners' perceptions towards using computers during out-of-class learning were explored.

\subsection{Research Methodology}

In this study, a questionnaire and interviews were the principal research methods used to collect data. Also, statistical analysis, content analysis and interpretative methods were employed to analyze the data. The themes in the questionnaire are listed in Table 1.

Table 1 . Themes addressed in questionnaires

\begin{tabular}{lll}
\hline & Themes addressed in questionnaires & $\begin{array}{l}\text { Statement Numbers } \\
\text { in Questionnaires }\end{array}$ \\
\hline Section I: Personal Information & $\begin{array}{l}\text { Course; Gender; Major; Computer } \\
\text { ownership and information about the } \\
\text { access to a learning facilities. }\end{array}$ & Questions 1-4 \\
$\begin{array}{l}\text { Section II: English Learning time } \\
\begin{array}{l}\text { Section III: Attitudes towards } \\
\text { using computers for EFL learning } \\
\text { out of class }\end{array}\end{array}$ & Out of class learning & Technology-based approaches \\
\hline
\end{tabular}

Interviews were undertaken with both the learners and their teachers in this study. The aim of the interview data collection from the teachers was to increase reliability of research findings by using triangulation of data sources (Rothbauer, 2008). All the interview questions were based on the questionnaire for the students in order to get more information and a deeper understanding related to the research questions and the aims of this study.

Table 2. Themes addressed in interview questions

\begin{tabular}{ll}
\hline Section I: Background Information & Themes addressed in interview questions \\
\hline $\begin{array}{l}\text { Section II: views on using computers for } \\
\text { EFL learning out of class }\end{array}$ & $\begin{array}{l}\text { Students: Course, Major and so on. } \\
\text { Teachers: teaching experiences (e.g. time) }\end{array}$ \\
\hline $\begin{array}{l}\text { Section III: Factors affecting students, } \\
\text { computer-assisted autonomous learning }\end{array}$ & $\begin{array}{l}\text { Motivation } \\
\text { Textbooks and technology, learner autonomy } \\
\text { (their relationship) }\end{array}$ \\
\hline $\begin{array}{l}\text { Section IV: Opinions on English language } \\
\text { and teaching }\end{array}$ & $\begin{array}{l}\text { Views on how to enhance computer-assisted } \\
\text { autonomous learning }\end{array}$ \\
\hline
\end{tabular}




\subsection{Research Participants}

Participants included non-English majors on different programmes from three colleges. 40 students were from a college attached to one of the leading universities in Southeast China, referred to as College A below. Additionally, 120 students attended the investigation from the other two colleges. One is in Southwest China, referred to as College $\mathrm{B}$ below, and the other is in Northeast China, referred to as College $\mathrm{C}$ below. Both College A and College $\mathrm{B}$ students were four-year Bachelor degree students, but the students from College $\mathrm{C}$ were three-year diploma students. The difference between Bachelor degrees students and three year diploma students in Chinese higher educational system is: the former ones study for 4 years at full-time in a college or university and after graduation they are awarded corresponding bachelor degrees dependent on their majors; the latter ones just study for three years and obtain certificates or diplomas without any degrees. Additionally, the degree students are required to pass the higher level English proficiency tests than the diploma students. Perhaps their perceptions might be influenced to a certain extent.

Table 3. Participants from different colleges

\begin{tabular}{lllll}
\hline & $\begin{array}{l}\text { College A } \\
\text { (4-year-degree } \\
\text { program) }\end{array}$ & $\begin{array}{l}\text { College B } \\
\text { (4-year-degree } \\
\text { program) }\end{array}$ & $\begin{array}{l}\text { College C } \\
\text { (3-year-diploma } \\
\text { program) }\end{array}$ & Total \\
\hline $\begin{array}{l}\text { Student numbers } \\
\text { (Percentage) }\end{array}$ & 40 & 60 & 60 & $160(100 \%)$ \\
\hline
\end{tabular}

\section{Findings of the Survey Research}

160 completed copies from 175 distributed questionnaires were obtained, with a response rate of $91 \%$. The qualitative and quantitative data analysis, based on student views, falls into three categories: 1) participants' access to computers; 2) the time spent by participants on different kinds of out of class English language learning, and 3) learners' perceptions towards using computers in out of class learning. Under each category, the results of closed-ended questions are presented in tables by frequency, percentage and, where appropriate, by the statistical mean. Unless otherwise stated, the number of participants in the presentation of the questionnaire data is equal to $160(\mathrm{~N}=160)$. The results of the open-ended questions and student interviews are presented and supported by quotes extracted from the data. In addition, the teachers' interview data will be used, where appropriate, in the discussion section. The purpose of the data collection from the teachers' interview is to increase credibility of research findings, as mentioned above.

\subsection{Participants' Access to the Use of Computers}

In this section, information regarding student access to computers is presented in Tables 4 and 5 respectively. Table 4 indicates that less than $40 \%$ of students owned their personal computers.

Table 4. Participants' computer ownership by frequency and percentage

\begin{tabular}{|c|c|c|c|}
\hline & & $\begin{array}{l}\text { The number of } \\
\text { the participants }\end{array}$ & Percentage \\
\hline \multirow{2}{*}{$\begin{array}{l}\text { Computer } \\
\text { ownership }\end{array}$} & Yes & 63 & $39.4 \%$ \\
\hline & No & 97 & $60.6 \%$ \\
\hline Total & & 160 & $100 \%$ \\
\hline
\end{tabular}

Moreover, Table 5 shows that among the students with personal computers, nearly 3 out of 10 could access the internet in their dormitories. 
Table 5. Participants' access to the use of computers

\begin{tabular}{|c|c|c|c|}
\hline & & $\begin{array}{l}\text { The number of } \\
\text { participants }\end{array}$ & Percent $(\%)$ \\
\hline \multirow{3}{*}{$\begin{array}{l}\text { Access to computers } \\
\text { by participants who } \\
\text { own a personal } \\
\text { computer. }\end{array}$} & $\begin{array}{l}\text { A: Access to the internet at a college } \\
\text { computer room or an Internet café. }\end{array}$ & 17 & $10.6 \%$ \\
\hline & $\begin{array}{l}\text { B: Access to the internet by using my } \\
\text { computer in my dormitory. }\end{array}$ & 45 & $28.1 \%$ \\
\hline & C: Access to the internet at home. & 2 & $1.3 \%$ \\
\hline \multirow{4}{*}{$\begin{array}{l}\text { Access to computers } \\
\text { by participants who } \\
\text { do not own a personal } \\
\text { computer. }\end{array}$} & $\begin{array}{l}\text { D: Often Access to the internet at an } \\
\text { internet café. }\end{array}$ & 15 & $9.4 \%$ \\
\hline & $\begin{array}{l}\text { E: Often access to the internet at a } \\
\text { college computer. }\end{array}$ & 61 & $38.1 \%$ \\
\hline & F: Do not use computers frequently. & 20 & $12.5 \%$ \\
\hline & Total & 160 & $100 \%$ \\
\hline
\end{tabular}

Because their personal computers were at home during the term time, more than $10 \%$ students had to go to an internet café or their college computer rooms to access the internet. However, among the students without their personal computers, nearly half of the total students had to get access to the internet at an internet café or their college computer rooms.

\subsection{The Time Spent on Different Kinds of Out-of-Class English Learning}

Table 6 examines the time spent on different kinds of out-of-class activities by participants on average per week.

Table 6. Time spent on different tasks or activities

\begin{tabular}{|c|c|c|c|c|}
\hline $\begin{array}{l}\text { Time (T): hours; } \mathrm{N}=\text { number of } \\
\text { respondents (percentage) }\end{array}$ & $\mathrm{T}=0$ & $0<\mathrm{T}<5$ & $5 \leq \mathrm{T} \leq 10$ & $\mathrm{~T}>10$ \\
\hline 5. Studying English after class & $\mathrm{N}=21(13.1 \%)$ & $\mathrm{N}=94(58.8 \%)$ & $\mathrm{N}=22(13.8 \%)$ & $\mathrm{N}=16(10.0 \%)$ \\
\hline $\begin{array}{l}\text { 6. Chatting on the Internet in Chinese, } \\
\text { playing games and any other relaxing } \\
\text { activities. }(\mathrm{N}=159)\end{array}$ & $8(5.0 \%)$ & $106(66.3 \%)$ & $38(23.8 \%)$ & $7(4.4 \%)$ \\
\hline 7. Chatting over the internet in English & $100(62.5 \%)$ & $51(31.9 \%)$ & $8(5.0 \%)$ & $1(0.6 \%)$ \\
\hline 8. Emailing in Chinese & $65(40.6 \%)$ & $87(54.4 \%)$ & $6(3.8 \%)$ & $2(1.3 \%)$ \\
\hline 9. Emailing in English & $117(73.1 \%)$ & $39(24.4 \%)$ & $3(1.9)$ & $1(0.6)$ \\
\hline $\begin{array}{l}\text { 10. Reading news and articles on Chinese } \\
\text { websites after class }\end{array}$ & $36(22.5 \%)$ & $110(68.8)$ & $10(6.3)$ & $4(2.5 \%)$ \\
\hline $\begin{array}{l}\text { 11. Reading news and articles on English } \\
\text { websites after class }\end{array}$ & $96(60.0 \%)$ & $54(33.8 \%)$ & $7(4.4 \%)$ & $3(1.9 \%)$ \\
\hline $\begin{array}{l}\text { 12. Practising English grammar and } \\
\text { vocabulary on the internet after class }\end{array}$ & $108(67.5 \%)$ & $41(25.6 \%)$ & $6(3.8 \%)$ & $5(3.1 \%)$ \\
\hline $\begin{array}{l}\text { 13. Practising listening on English } \\
\text { language learning websites or by using } \\
\text { software on CDs or DVDs after class }\end{array}$ & $86(53.8 \%)$ & $67(41.9 \%)$ & $5(3.1 \%)$ & $2(1.3 \%)$ \\
\hline $\begin{array}{l}\text { 14. Practising English listening by using an } \\
\text { MP3, tape recorder or repeater after class }\end{array}$ & $65(40.6 \%)$ & $79(49.4 \%)$ & $14(8.8 \%)$ & $2(1.3 \%)$ \\
\hline $\begin{array}{l}\text { 15. Reading English books or journals after } \\
\text { class. }\end{array}$ & $43(26.9 \%)$ & $98(61.3 \%)$ & $19(11.9 \%)$ & 0 \\
\hline $\begin{array}{l}\text { 16. Practising spoken English in a } \\
\text { dormitory or at an English conversation } \\
\text { corner }\end{array}$ & $92(57.5 \%)$ & $63(39.4 \%)$ & $2(1.3 \%)$ & $3(1.9 \%)$ \\
\hline $\begin{array}{l}\text { 17. Practising writing compositions and } \\
\text { diary in English after class }\end{array}$ & $81(50.6 \%)$ & $70(43.8 \%)$ & $9(5.6 \%)$ & 0 \\
\hline
\end{tabular}


The following items ( 1 to 8 ) are based on Table 6. Also, the findings and the brief explanations are presented according to the statistics of the table.

1) Just over $13 \%$ of students did not spend any time studying English after class and nearly one quarter of students spent more than 5 hours on average each week.

2) $95 \%$ of the students spent some time in chatting on the internet in Chinese, playing games and any other activities during the week. However, nearly $40 \%$ of students spent some time chatting in English.

3) $60 \%$ of students spent some time emailing in Chinese, but one quarter of the students emailed in English.

4) More than three quarters read news and articles on Chinese websites after class, but only $40 \%$ of students read news and articles on English websites.

5) Nearly one third of the students practised English grammar and vocabulary on the internet.

6) Less than half of the students practised listening on English language learning websites or with software on CDs or DVDs. By contrast, nearly $60 \%$ of students practised listening with the use of an MP3 player, recorder or repeater after class.

7) Nearly three out of four students spent some time reading English books or journals. Among them, nearly $12 \%$ of students spent more than five hours a week. Less than 50\% of students practised speaking English with their classmates or their friends in a dormitory or at an English conversation corner. Also, nearly half of the students practised writing, such as keeping a diary or writing English compositions.

8) From the findings on different types of out of class activities, it can be seen that more students spent time practising listening on the internet or with software (accessed from computers) and by reading English books/journals after class without accessing computers.

\subsection{Learners' Perceptions towards Out-of-Class Computer-Assisted Learning}

In Section III of the questionnaire, there were eight statements about attitudes towards using computers for EFL learning out of class in China's colleges or universities. Table 7 shows the learners' perceptions towards out-of-class learning by the computers (the number of respondents and percentage). Also, this section of the questionnaire was designed to measure attitudes towards learner autonomy by offering scales for positive attitudes (strongly agree $=5$, agree $=4$, neutral $=3$, disagree $=2$, strongly disagree $=1$ ). Table 7 also indicates the mean score for each item.

Table 7. Learners' perceptions towards using computers in out of class learning

\begin{tabular}{|c|c|c|c|c|c|c|}
\hline $\begin{array}{l}\text { Each Total Number }=160 \text {, except Items } \\
18 \text { and } 19\end{array}$ & $\begin{array}{c}\text { Strongly } \\
\text { agree }\end{array}$ & Agree & Neutral & Disagree & $\begin{array}{l}\text { Strongly } \\
\text { disagree }\end{array}$ & Mean \\
\hline $\begin{array}{l}\text { 18. Easier to learn English by using } \\
\text { computers than by using books. }(\mathrm{N}=159)\end{array}$ & $\begin{array}{c}24 \\
(15.0 \%)\end{array}$ & $\begin{array}{c}64 \\
(40.0 \%)\end{array}$ & $\begin{array}{c}50 \\
(31.3 \%)\end{array}$ & $\begin{array}{c}18 \\
(11.3 \%)\end{array}$ & $\begin{array}{c}3 \\
(1.9 \%)\end{array}$ & 3.55 \\
\hline $\begin{array}{l}\text { 19. More effective to learn English by } \\
\text { using computer software than other ways, } \\
\text { such as tape recorders. }(\mathrm{N}=159)\end{array}$ & $\begin{array}{c}25 \\
(15.6 \%)\end{array}$ & $\begin{array}{c}65 \\
(40.6 \%)\end{array}$ & $\begin{array}{c}55 \\
(34.4 \%)\end{array}$ & $\begin{array}{c}12 \\
(7.5 \%)\end{array}$ & $\begin{array}{c}3 \\
(1.9 \%)\end{array}$ & 3.61 \\
\hline $\begin{array}{l}\text { 20. Reading English websites will } \\
\text { develop reading ability more than reading } \\
\text { English textbooks. }\end{array}$ & $\begin{array}{c}14 \\
(8.8 \%)\end{array}$ & $\begin{array}{c}51 \\
(31.9 \%)\end{array}$ & $\begin{array}{c}61 \\
(38.1 \%)\end{array}$ & $\begin{array}{c}31 \\
(19.4 \%)\end{array}$ & $3(1.9)$ & 3.26 \\
\hline $\begin{array}{l}\text { 21. Using English websites is one of the } \\
\text { most effective ways to learn English. }\end{array}$ & $\begin{array}{c}20 \\
(12.5 \%)\end{array}$ & $\begin{array}{c}58 \\
(36.3 \%)\end{array}$ & $\begin{array}{c}60 \\
(37.5 \%)\end{array}$ & $\begin{array}{c}18 \\
(11.3 \%)\end{array}$ & $\begin{array}{l}3 \\
(1.9 \%)\end{array}$ & 3.47 \\
\hline $\begin{array}{l}\text { 22. Emailing in English will enhance } \\
\text { English writing proficiency. }\end{array}$ & $\begin{array}{c}37 \\
(23.1 \%)\end{array}$ & $\begin{array}{c}87 \\
(54.4 \%)\end{array}$ & $\begin{array}{c}27 \\
(16.9 \%)\end{array}$ & $6(3.8 \%)$ & $\begin{array}{l}3 \\
(1.9 \%)\end{array}$ & 3.93 \\
\hline $\begin{array}{l}\text { 23. Chatting in English on the internet } \\
\text { will improve spoken English. }\end{array}$ & $\begin{array}{c}43 \\
(26.9 \%)\end{array}$ & $\begin{array}{c}85 \\
(53.1 \%)\end{array}$ & $\begin{array}{c}24 \\
(15.0 \%)\end{array}$ & $6(3.8 \%)$ & $\begin{array}{l}2 \\
(1.3 \%)\end{array}$ & 4.01 \\
\hline $\begin{array}{l}\text { 24. The use of IT (Information } \\
\text { Technology) will solve problems in } \\
\text { English teaching in China. }\end{array}$ & $\begin{array}{c}27 \\
(16.9 \%)\end{array}$ & $\begin{array}{c}62 \\
(38.8 \%)\end{array}$ & $\begin{array}{c}48 \\
(30.0 \%)\end{array}$ & $\begin{array}{c}22 \\
(13.8 \%)\end{array}$ & $\begin{array}{c}1 \\
(0.6 \%)\end{array}$ & 3.58 \\
\hline $\begin{array}{l}\text { 25. One of the most effective ways to } \\
\text { assist English teaching is to apply } \\
\text { advanced technology. }\end{array}$ & $\begin{array}{c}29 \\
(18.1 \%)\end{array}$ & $\begin{array}{c}87 \\
(54.4 \%)\end{array}$ & $\begin{array}{c}36 \\
(22.5 \%)\end{array}$ & $6(3.8 \%)$ & $\begin{array}{c}2 \\
(1.3 \%)\end{array}$ & 3.84 \\
\hline
\end{tabular}




\subsubsection{Findings from Table 7}

1). (Items 22 and 23): Nearly $80 \%$ of the students positively believed that emailing in English enhances English writing proficiency. Additionally, $80 \%$ of the students held more positively the attitude that chatting in English on the Internet improves spoken English. Also, these two items have the highest mean.

2). (Items 19, 21 and 25): More than half of the students agreed (or strongly agreed) with the view that it is easier and more effective to learn English by using computers and computer software. However, around one third of the students were neutral for Item 19. In Item 21, less than half of the students held the view that using English websites is one of the most effective ways to learn English. Item 25 shows that nearly three quarters of the students firmly believed that one of the most effective ways to assist English teaching is to use advanced information technology.

3). (Item 20): Only $40.7 \%$ of the students held the view that reading articles or books on English websites will develop reading ability more than reading English language textbooks.

4). (Item 24): When asked if using IT could solve some of the problems in English language learning in China, more than half of the students agreed (strongly) with the view.

\subsubsection{The Findings from the Students' Interviews}

When asked which way is more convenient to learn English, two interviewees answered by using computers, two answered using books and the other two answered both. When asked which way is more effective to learn English, six answered both computers and the internet. One of the interviewees commented that: "both computers and books have advantages and disadvantages. We can combine the two advantages into one. We should maximize their strong points and try to minimize their weak points in order to enhance our language learning efficiency. For example, computers are convenient for practising listening and speaking, sometimes reading and writing. Also, internet resources are very rich. Although books are very convenient to carry, computers connected to the internet are incomparable in terms of language learning. On the whole, computers are much more advantageous than books as far as language learning is concerned."

\section{Discussion of the Findings}

\subsection{The Participants' Access to the Use of Computers}

The findings above in Table 4.2 shows that more than $60 \%$ of students did not own a personal computers, but nearly $90 \%$ of participants had access to the internet or used computers in different places, except for the $12.5 \%$ of students who cannot use computers frequently. Although the rate of the computer ownership among students in these higher education organizations is very low, the rate of computer usage is much higher, which reflects Petrina's view (2007) that computer technology plays a vital role in higher education, and helps students access information quickly and conveniently. The use of computers as a learning tool has also laid solid foundations for their studies.

\subsection{Analysis of the Time on Various Type of English Language Learning}

The finding indicates that most students used computers for a long time but not for studying English (see Table 4.3). In particular, $95 \%$ students spent more time per week chatting over the internet in Chinese, playing games and performing any other leisure activities rather than studying English after class. By some accounts of learner autonomy (Benson, 2011), there are problems in out-of-class learning management for students in their studies. In other words, they could not manage their studies by themselves. On the other hand, they were lacking the ability to take charge or control over their studies.

From the other findings, such as time spent studying English by using computers and studying English without computers, it can be seen that the students spent more time in the latter than in the former. However, in some universities or colleges, even if the students owned their computers, they were not allowed to bring them to their universities or colleges in the first year. Thus, to some degree, their English study or other courses may be affected by their unavailability to use computers.

It is clearly shown in Table 4.3 that the students spent more time practising listening skills using the Internet or software than practising reading, writing and speaking skills. According to second language acquisition theories, second language learners should first consider developing their listening and reading skills, called input skills before they can develop their other language speaking and writing skills. Therefore, undoubtedly, it was right for students to first focus on listening and reading more than on the other language skills. Although the students spent less time on computers to study English than studying without computers, technological aids can be used 
effectively for independent work and the role of technological aids plays a key role in the development of the four basic language skills (Pachler \& Field, 2001).

\subsection{Analysis of Learners' Perceptions towards Using Computer for Out-of-Class Learning}

From the above findings in the attitudes of learners towards using computers for out-of-class learning, more than half held the view that using computers, or IT or other advanced technology to learn English, is more effective than other tools on the whole. Their attitudes parallel the view of Pachler and Field (2001) that technological aids can be used effectively for independent work and can develop the four language skills.

More than half of the students agree (strongly) with the view that CD-ROMs are more effective, compared to tape recorders. It seems that their perceptions towards using CD-ROMs in language learning may reflect from the research conducted by Kaltenböck (2001) because one of the advantages of technologies, such as CD-ROMs, for language learning is their emphasis on learner independence, with CD-ROMs providing a high degree of flexibility in the learning process (Kaltenböck, 2001).

The more significant finding is that nearly $80 \%$ of the students believed positively that emailing in English enhances their English writing proficiency. This supports the findings of a research project on the written English communication via the internet and English language learning, conducted by Jin (2006). Twenty Chinese students in Suzhou University communicated with 28 American students at the Southern Polytechnic University of Georgia via email on several practical topics such as Chinese culture and American culture for 12 weeks. The findings from this experiment indicate clearly that the Chinese students increased greatly their vocabulary and expressions in authentic English, and not only their English writing improved but also their spoken English from their partners and native English speakers.

A further significant finding was that $80 \%$ of the students held more positively the attitude that chatting in English over the internet improves spoken English. Nowadays, technology develops very fast. People can use network-based communications (NBC) to communicate with each other in real time with instant messaging tools, their obvious advantage being that messages are typed, sent and received instantaneously (Pellettieri, 2000). Pellettieri's study on NBC demonstrates that it can indeed foster the negotiation of meaning and can also play a significant role in the development of grammatical competence.

The final significant finding is that more than half of the students firmly believed that using IT will solve English language learning problems, such as 'deaf and dumb English' in China. Several researchers have elaborated on the relationship between IT and learner autonomy and described autonomy and types of applications. Also, Schwienhorst (2003) discusses the conditions that enhance autonomy and learning, pointing out that technology can be a valuable tool for autonomous learning.

From the students' interviews, it can be also seen that using advanced technology is one of the most effective ways to learn and teach English. Regarding Chinese higher education students, digital media players such as MP3 have been used to learn English, because they are more convenient to learn from and have more functions than other non-digital machines, such as tape recorders. Additionally, the more effective ways to learn English should make full use of the combination of the advantages of both computers and books and that maximize their own strong points and minimize their own weak points.

From the interviews, the teachers thought that computers could help them and students in teaching and learning English. It was also obvious that computers offer more interesting learning resources. They held the same view as the students. From the above analysis, we can see that students and teachers basically have the same opinions or attitudes towards using computers to learn English.

\section{Implications, Recomendations and Conclusions}

\subsection{The Importance for English Language Learners of Managing their Time after Class}

From Table 6, it was found that the students spent much more time chatting, emailing and reading news and articles in Chinese rather than in English.

As the students spent more time on computers doing these activities rather than on other courses, including English study, it seems that the most important thing for teachers is to guide their students and encourage them to learn English autonomously using computers. Also, teachers should motivate their students to manage their time wisely out of class because the learning time of wise and effective management can help learners to achieve more from their studies (Schunk, 2012). 


\subsection{Student Perceptions towards Computer-Assisted Autonomous Learning to Enlighten Learning and Teaching}

As mentioned above, some significant findings on student perceptions towards computer-assisted autonomous learning are: the use of computers is more convenient or more effective for English learning than using other learning tools, such as tape recorders; emailing and chatting in English over the internet will improve English proficiency; IT or other advanced technology may solve learning problems, such as "time-consuming low effect" and "deaf and dumb English", in China.

From the above findings, whether from the questionnaire or the interviews, it was widely believed that learner autonomy is one of the most important learning methodologies in language learning. Therefore, the combination of learner autonomy and the use of computers may be one of the most effective ways in learning English.

\subsection{The Significance of Both Students' and Teachers' Views on Effective Computer-Assisted English Learning}

From the above discussion on the effectiveness of CD-ROMs and CALL, it is concluded that textbooks with a CD-ROM may be better than textbooks without a CD-ROM. CALL courses may be much better than other learning tools, such as tape recorders. The views from both questionnaire and interviews have been confirmed by some similar researches, theoretically and empirically (Benson, 2011). The students' suggestions and expectations for CALL have been examined by researchers (Nielson, 2011). These findings play a significant role in English language learning in China's higher education.

\subsection{Recommendations}

According to the findings of this study, I would like to propose 5 tentative recommendations on the English language learning and teaching by using learner autonomy and computers in China.

1) Enhance the teachers' training.

Due to the English language teachers work load in China, they have had no time for further study. It is suggested that every university or college should focus on the teachers' training, especially on technology training such as basic and practical computer technology, the latest or new language teaching methodology (methods) and so on.

2) Edit English Textbooks with CD-ROM and the relevant learning websites.

It is suggested that Chinese editors or writers of the College English textbooks should learn the advantages of the similar level English textbooks from the other countries and edit or write a set of textbooks accompanying CD-ROM and the relevant learning websites, which will be suitable to the English language learners in China. Additionally, it is suitable for the students to learn them independently out of class.

3) Educational authorities should invest more on Computer service or learning facilities for the students in order that students' requirements such as learning English or the other subjects by computers autonomously can be met.

4) Based on this investigation, it is suggested that effective computer software or programmes which are suitable for Chinese students should be developed so that students can enhance their learning efficiency. Meanwhile, they are helpful and useful to promote learner autonomy.

5) The researchers or language teachers should explore some more effective teaching methods and develop more software/computer programmes or English language learning websites with creativity, which can assist students to improve their language proficiency as soon as possible.

\subsection{Conclusions}

Finally, to conclude, this study has basically achieved its aims. It is believed that with the rapid development of modern technologies, the wide use of computers and the internet will lead to a new revolution in the field of education, which will bring about a greater improvement in the quality of education and learning.

\section{References}

Benson, P. (2011). Teaching and Researching: Autonomy in Language Learning. London: Pearson Education.

Crabbe, D. (1993). Fostering autonomy from within the classroom: The teacher's responsibility. System, 21(4), 443-452. http://dx.doi.org/10.1016/0346-251X(93)90056-M

Dickinson, L. (1995). Autonomy and Motivation: A Literature Review. System, 23(2), 165-174. http://dx.doi.org/10.1016/0346-251X(95)00005-5

Hafner, C., \& Miller, L. (2011). Fostering learner autonomy in English for Science: A collaborative digital video project in a technological learning environment. Language Learning \& Technology, 15(3), 68-86.

Jin, L. (2006). Written English Communication on the Internet and English Language Learning. In P. Gu (Ed.), 
CALL Theory and Practice (pp. 312-315). Shanghai, China: Fudan University Press.

Jones, J. (2001). CALL and the responsibilities of teachers and administrators. ELT Journal, 55(4), 360-367. http://dx.doi.org/10.1093/elt/55.4.360

Kaltenböck, G. (2001). Learner autonomy: A guiding principle in designing a CD-ROM for intonation practice. ReCALL, 13(2), 179-190. http://dx.doi.org/10.1017/S0958344001000428a

Nielson, K. (2011). Self-study with language learning software in the workplace: What happens? Language Learning \& Technology, 15(3), 110-129.

Pachler, N., \& Field, K. (2001). Learning to teach modern foreign languages in the secondary school: A companion to school experience. London: Routledge.

Pellettieri, J. (2000). Negotiation in cyberspace: The role of chatting in the development of grammatical competence. In M. Warschauer, \& R. Kern (Eds.), Network-Based Language Teaching: Concepts and Practice (pp. 59-86). Cambridge: Cambridge University Press. http://dx.doi.org/10.1017/CBO9781139524735.006

Petrina, S. (2007). Advanced Teaching Methods for the Technology Classroom. London: Information Science Publishing.

Reinders, H. (2007). Big brother is helping you: Supporting self-access language learning with a student monitoring system. System, 35(1), 93-111. http://dx.doi.org/10.1016/j.system.2006.10.009

Rothbauer, P. M. (2008). Triangulation. In L. S. Given (Ed.), The SAGE Encyclopedia of Qualitative Research Methods (Vol. 1-2., pp. 892-894). London and Los Angeles: SAGE.

Schmenk, B. (2005). Globalizing Learner Autonomy. TESOL Quarterly, 39(1), 107-118. http://dx.doi.org/10.2307/3588454

Schunk, D. (2012). Learning Theories: An Educational Perspective (6th ed.). Boston: Pearson Education.

Schwienhorst, K. (2003). Learner autonomy and tandem learning: Putting principles into practice in synchronous and asynchronous telecommunications environments. Computer Assisted Language Learning, 16(4), 427-443. http://dx.doi.org/10.1076/call.16.5.427.29484

Schwienhorst, K. (2007). Learner Autonomy and CALL Environments. Oxon: Routledge.

\section{Copyrights}

Copyright for this article is retained by the author(s), with first publication rights granted to the journal.

This is an open-access article distributed under the terms and conditions of the Creative Commons Attribution license (http://creativecommons.org/licenses/by/3.0/). 